\title{
Az ovarialis hiperstimulációs szindróma kórélettana és korszerü klinikuma
}

\author{
Szabó Gábor dr. - Árokszállási Anikó dr. - Pócsi Dóra dr. \\ Murber Ákos dr. - Urbancsek János dr. - Rigó János Jr. dr.
}

Semmelweis Egyetem, Általános Orvostudományi Kar, I. Szülészeti és Nőgyógyászati Klinika, Budapest

\begin{abstract}
Az asszisztált reprodukciós kezelések során a petefészkek szabályozott stimulációja történik. Az ovarialis hiperstimulációs szindróma a meddőségi kezelés során a petefészek túlzott válaszreakciójának következménye. Ritkán egyéb ok, például a folliculusstimulálóhormon-receptor mutációjának következménye is lehet. A betegség következményeként az intravascularis folyadék a harmadik (extracelluláris) folyadéktérbe, fő́ként a hasüregbe vándorol. Túlstimulálódás esetén a klinikai jelek a hasfeszüléstől, a megnövekedett petefészkeken és az ascitesen keresztül a vénás vagy artériás thromboemboliás szövődményekig mutatkozhatnak. A betegség súlyos formájában életveszélyes állapotot is okozhat, ha ischaemiás stroke vagy végtagkeringési elégtelenség alakul ki. Az elmúlt években számos új módszer került bevezetésre a tünetegyüttes kialakulásának megelőzésére. Az ovarialis hiperstimulációs szindróma iatrogén, súlyos formájában életveszélyes állapot, mely fiatal, a meddőségtől eltekintve egyébként egészséges embereket érint. A betegség gazdasági hatása számottevő. A munkakiesés, a kórházi bennfekvés és súlyos esetekben az intenzív ellátás költségei tetemesek. Továbbra is a szupportív kezelés, az antikoaguláns profilaxis, valamint a szoros megfigyelés a szindróma bázisterápiája. Súlyos, illetve kritikus állapotú betegeknél azonban a kórházi felvétel, illetve beavatkozás nem késlekedhet.
\end{abstract}

Orv Hetil. 2018; 159(34): 1390-1398.

Kulcsszavak: ovarialis hiperstimulációs szindróma, ultrahang-képalkotás, prevenció, intenzív kezelés

\section{Pathophysiology and current clinical approach of ovarian hyperstimulation syndrome}

During assisted reproduction technologies, controlled hyperstimulation of the ovaries occurs. Ovarian hyperstimulation syndrome is an excessive overreaction of the ovaries complicating pharmacological ovulation induction. Rarely other causes, such as the mutation of the follicle-stimulating hormone receptor may also be in the background. Ovarian hyperstimulation syndrome is clinically characterized by a massive ovarian enlargement associated with an acute third-space fluid shift responsible for the development of ascites, and sometimes pleural or pericardial effusion. Associated arterial or venous thromboembolic symptoms are also common. Ovarian hyperstimulation syndrome is an iatrogenic and potentially life-threatening condition in the form of ischemic stroke or circulatory insufficiency of the limbs. Recently some new methods have been developed for the prevention of the disease. The syndrome affects young, healthy patients. It also has an important economic burden due to the absence from work, bed rest, or hospitalization and intensive medical management of more severe cases. Supportive therapy, anticoagulant prophylaxis and close monitoring are the main approach for the syndrome. However, hospitalization or intervention should not be delayed for patients with severe or critical conditions.

Keywords: ovarian hyperstimulation syndrome, ultrasound imaging, prevention, intensive care

Szabó G, Árokszállási A, Pócsi D, Murber Á, Urbancsek J, Rigó J Jr. [Pathophysiology and current clinical approach of ovarian hyperstimulation syndrome]. Orv Hetil. 2018; 159(34): 1390-1398.

(Beérkezett: 2018. április 10.; elfogadva: 2018. május 2.)

\section{Rövidítések}

$\mathrm{AMH}=$ anti-Müller-hormon; ARDS $=$ (acute respiratory distress syndrome) akut légúti distressz szindróma; ASRM = (American Society for Reproductive Medicine) Amerikai Rep- rodukciós Orvostani Társaság; BMI = (body mass index $)$ testtömegindex; $\mathrm{COH}=$ (controlled ovarian hyperstimulation) ellenőrzőtt petefészek-túlstimuláció; CRP = C-reaktív protein; $\mathrm{FSH}=$ folliculusstimuláló hormon; GFR = glomerulusfiltrációs 
ráta; $\mathrm{GnRH}=$ (gonadotropin-releasing hormone) gonadotropinfelszabadító hormon; hCG = humán choriogonadotropin; IVF $=($ in vitro fertilization $)$ szervezeten kívüli megtermékenyítés; $\mathrm{LH}=$ luteinizáló hormon; $\mathrm{mRNS}=$ (messenger $)$ hírvivő ribonukleinsav; OHSS $=$ (ovarian hyperstimulation syndrome $)$ ovarialis hiperstimulációs szindróma; $\mathrm{PCO}=$ (polycystic ovarian syndrome $)$ polycystás ovarium szindróma; $\mathrm{RCOG}=($ Royal College of Obstetricians and Gynecologists) Királyi Szülészeti és Nőgyógyászati Kollégium; SGOC = (The Society of Obstetricians and Gynaecologists of Canada) Kanadai Szülészeti és Nőgyógyászati Társaság; TSH = tireotropstimuláló hormon; VEGF $=$ (vascular endothelial growth factor $)$ vascularis endothelialis növekedési faktor; WHO $=$ (World Health Organization) Egészségügyi Világszervezet

\section{Történeti áttekintés}

Az ovarialis hiperstimulációs szindrómát (OHSS) 1943ban írták le először. Ekkor a petefészkek „túlzott hiperluteinizációját” találták vemhes kancák szérumával, illetve juhok agyalapimirigy-kivonatával embereken végzett ovulációindukciós kezelés kapcsán [1]. Az, hogy a kórkép életveszélyes szövődményekkel járhat, hamar felismerésre került. Végzetes oligo-, anuriát okozó veseelégtelenséggel járó szövődményt már 1951-ben publikáltak [2]. Az elmúlt évtizedekben a meddőségi kezelések során alkalmazott petefészek-stimulációs módszerek mindegyikénél kialakulhatott szövődményként különböző súlyosságú OHSS. A betegség jobb megismerésével, az ultrahangvizsgálatok elterjedésével és az asszisztált reprodukciós kezelések számának növekedésével egyre több eset kerül felismerésre.

\section{Előfordulás, gyakoriság}

Az ovarialis hiperstimulációs szindróma gyakorisága függ a meddőségi kezelés okától és formájától is $[3,4]$. Klomifén-citrát vagy aromatázinhibitor adásával végzett petefészek-stimuláció után terminált együttlét, vagy intrauterin inszemináció esetén az OHSS enyhe formája az esetek 8,0-23\%-ában, középsúlyos formája 0,005-7\%ban és súlyos forma 0,008-10\%-ban alakul ki. In vitro fertilizáció céljából alkalmazott gonadotropinstimuláció esetén az enyhe forma különböző mértékben ugyan, de közel 100\%-ban, a középsúlyos forma 21-44\%-ban és a súlyos forma 1-10\%-ban jelentkezik. A becsült mortalitás: 1 : 45 000-1 : 500 000/beteg közötti. A WHO az OHSS súlyos formájának incidenciáját 0,2-1\% közöttire becsüli a stimulációs ciklusokra vonatkoztatva [5]. Egyes vizsgálatok növekvő tendenciát találtak [6].

\section{Hajlamosító tényezők}

A kórképre az adott stimulációs kezeléstôl független számos hajlamosító tényezőt írtak le. Ezek közé tartozik a kórelőzményben szereplő hiperstimulációs szindróma is. Az alkati tényezők közül a fiatal életkor (30 év alatt), a testsúly (alacsony BMI) és a negrid rassz származás emelendő ki. Ezen jellegek általános mivolta azonban nem teszi lehetővé az asszisztált reprodukciós kezelés előtti kockázati besorolást.

Az ovuláció zavarával járó polycystás ovarium szindróma (PCO, hyperinsulinaemia, magas ösztradiolszint, nagyszámú éretlen folliculus gyors növekedése a stimuláció során) szintén kockázati tényező [7]. Az inzulin a vascularis endothelialis növekedési faktor (VEGF) expressziójának és szekréciójának fokozódását is okozza. Tummon és mtsai adatai alapján a PCO-s pácienseknél közel hétszeres valószínúséggel alakul ki OHSS a nem PCO-s páciensekhez képest [8]. Sokkal érzékenyebb előrejelző módszer a granulosasejtek által termelt, így a petefészek rezervkapacitására jellemző anti-Müller-hormon $(\mathrm{AMH})$ bazális szérumszintjének meghatározása. A marker alkalmazását segíti, hogy az AMH szintje a menstruációs ciklus során, illetve az egymást követő ciklusokban is viszonylag stabil [9]. A gyakorlatban a 3,36 $\mathrm{ng} / \mathrm{ml}$ feletti AMH-érték magas specificitással jelzi az ovarialis hiperstimulációs szindróma kialakulását [10]. Szintén emeli a kockázatot, ha ultrahangvizsgálattal a stimuláció előtt az antralis folliculusok száma 12 feletti.

A kezelés során is előfordulnak olyan paraméterek, amelyek elöre jelezhetik a fokozott válaszreakció kialakulását. Ilyen a magas vagy hirtelen emelkedő szérumösztradiolkoncentráció. $6000 \mathrm{pg} / \mathrm{ml}$ vagy $22 \mathrm{pmol} / \mathrm{l}$ feletti ösztradiolértéknél az esetek több mint 1\%-ában alakult ki súlyos OHSS. Ha a stimuláció során a $10 \mathrm{~mm}$ átmérő feletti tüszők száma több, mint 20, az szintén kockázatemelőként értékelendő $[10,11]$. Az in vitro fertilizáció céljából a tüszőkből nyert petesejtek számának növekedésével szintén nő a hajlam.

A stimulációs protokoll során alkalmazott gyógyszerek típusa is befolyásolja a kockázatot. A tüszőérést serkentő gonadotropin adásával párhuzamosan a korai, spontán luteinizálóhormon (LH)-csúcs elkerülése céljából adott gonadotropinfelszabadítóhormon (GnRH, gonadotropinreleasing hormone)-agonista kezelés esetében gyakrabban alakult ki hiperstimulációs szindróma, mint a hasonló célból adott GnRH-antagonisták alkalmazása esetén.

A stimuláció után másodlagos hajlamosító tényezőt jelent a humán choriogonadotropin (hCG) alkalmazása akár ovulációindukció céljából, akár később a lutealis fázisban progeszteron helyett a sárgatest múködésének támogatására [12]. Amennyiben terhesség fogan, akkor az mint endogén hCG-forrás szintén emeli az OHSS kialakulásának valószínűségét. Ezt támasztja alá, hogy az ikerterhesek között emelkedett az OHSS gyakorisága a szinguláris terhesekhez képest [13].

Fontos hangsúlyozni, hogy jelenleg egyetlen rizikótényező vagy ezek kombinációja sem tudja teljes biztonsággal előre jelezni vagy kizárni a hiperstimuláció kialakulását. Az is megállapítható, hogy minden, gonadotropinokkal indított petefészek-stimulációs kezelés magában hordozza a túlstimulációs szindróma kialakulásának veszélyét, ezért a pácienseket ennek lehetőségéről tájékoztatni kell. 


\section{Kórélettan}

Az OHSS kórélettana, illetve az, hogy miért az adott egyénnél alakul ki a betegség, napjainkban sem teljesen ismert. Élettani, „in vivo” ciklusokban részben petefészken belüli folyamatok (például inhibin hatása), részben a hypothalamus-hypophysis-petefészek rendszernek a viszszacsatolások révén szabályozott múködése korlátozza a korai antralis folliculusok kiválasztódását. E kiválasztódási folyamat eredményeképpen a domináns érett tüsző megrepedése (ovuláció) követi a középidős LH-csúcsot.

Az in vitro fertilizációs kezelés során megfelelő számú petesejt nyerése és embrió visszaültetése a cél. Az ellenőrzőtt petefészek-túlstimuláció (controlled ovarian hyperstimulation, $\mathrm{COH}$ ) érdekében adott gonadotropinok felborítják a visszacsatolások által fenntartott egyensúlyt. A gonadotropinokkal végzett petefészek-stimuláció hatására nagyszámú tüsző fejlődése indul meg [14].

Először nagyszámú korai antralis tüsző választódik ki, melyek az ovulációig növekednek. Magas szérum-ösztradiolkoncentráció mérhető, és a stimuláció végén a petefészkek megnagyobbodása látható ultrahangvizsgálattal. Ekkor külső hCG adása következik a tüszőérés végső lépésének és az ovuláció kiváltásának céljából. A hCG kulcsszerepet játszik a granulosasejtek lutealis átalakulásában, így a betegség kialakulásában. A hCG féléletideje hosszabb az endogén LH-énál, így biológiai aktivitása hatszor nagyobb annál. Egyéb módon kiváltott, például GnRH-agonisták által végzett ovulációindukció nem vezet extrém mértékű luteinizációhoz.

A luteinizálódó tüszőkben számos vazoaktív anyag szerepét vizsgálták a hCG-adás után fokozódó kapilláris permeabilitás növekedésével kapcsolatban (1. ábra). A tüszők nagy mennyiségben VEGF-t termelnek. A kórképre hajlamos egyénnél a tüsző érésének végső lépését és az ovulációt kiváltó hCG-kezelés indítja el a fokozott VEGF-képződést a petefészkekben. Megfogant terhesség esetén a hCG endogén termelődése tartja fenn a magas VEGF-szintet. A VEGF a heparinkötő fehérjék családjába tartozik, mely közvetlenül az endothelsejtek felszínén hatva azok osztódását serkenti, illetve érújdonképződést generál. A tüszőérés során és az ovuláció után a granulosa- és a thecasejtekben a VEGF mRNS-e expresszálódik.

A petefészkekben a folliculusok körül neovascularisatio indul (2. ábra). Az új erek helyi permeabilitásnövekedése a tüszőfolyadék VEGF-tartalmának és a granulosa-, valamint a lutealis sejtek által termelt egyéb vazoaktív és angiogén anyagoknak (például renin) a hasüregbe jutását okozza, ahonnan a szisztémás keringésbe szívódnak fel [15]. Ezek az anyagok a renin-angiotenzin rendszer aktiválása mellett az erek falában a hCG adása után felszaporodó VEGF-receptorokhoz is kötődnek. A következmény testszerte a kapillárisok folyadékra vonatkozó átjárhatóságának növekedése, ezáltal folyadékvesztés a harmadik (extracelluláris) víztérbe [16, 17]. Hasűri, mellkasi vagy pericardialis folyadékgyülem jön létre, és egyúttal hypovolaemia alakul ki. Súlyos OHSS miatt kezelt betegek ascitesében a VEGF kimutatható [18]. A VEGF szérumkoncentrációja egyenes arányban áll az OHSS kialakulásának kockázatával és súlyosságával. A hCG adása után nemcsak az endothel-, hanem a granulosa-lutealis sejtek felszínén is kimutatható a VEGF2-receptor. A VEGF-VEGF2 receptorok kapcsolatában a sejtek közötti kadherinek játszanak szerepet [19].

Az OHSS tehát a petefészkek szabályozott stimulációjára adott, az élettanihoz képest fokozott válaszreakciót jelent.

Az ovulációindukciós és in vitro fertilizációs kezelésekhez kapcsolódó patomechanizmuson kívül más okok is vezethetnek az OHSS kialakulásához. Ilyen lehet a gonadotropinok irányába fokozott érzékenységet okozó folliculusstimulálóhormon (FSH)-receptor mutációja. Ebben az esetben az endogén hCG is liganddá válhat az FSH-receptor számára [20]. Számos publikáció írt le spontán fogant terhesség kapcsán, akár visszatérően is jelentkező, súlyos fokú OHSS-t ilyen jellegú mutációk esetén [21-23]. Az FSH-receptor expresszióját negatív irányba szabályozó egyéb fehérjék, például a BMPl5 (bone morphogenetic protein 15) csökkent múködését okozó mutációja szintén növeli az OHSS kialakulásának kockázatát [24].

A betegség kialakulásához vezethet a hCG kórosan magas szintje molaterhességben vagy FSH-termelő gonadotropadenoma fogamzóképes nők esetében. A gonadotropinokhoz hasonló molekulák - például hypothyreosis esetén a TSH túltermelődésekor - az FSH-receptorokhoz kötődve a terhesség alatt szintén hiperstimulációhoz vezethetnek [25]. Leírtak a hasnyálmirigyben kialakult, FSH-t termelő és a petefészek hiperstimulációjához vezető neuroendokrin daganatot is az irodalomban [26].

\section{Klinikai tünetek, szövődmények}

A kórélettani elváltozások következményeként alakulnak ki az ovarium hiperstimulációs szindróma tünetei. Korai szubjektív panasz a has feszülése, párhuzamosan a petefészkek méretének növekedésével [27]. Ezek egyrészt bimanuális, másrészt ultrahangvizsgálattal jól felismerhetők. A petefészkek jellegzetesen sok tüszőt vagy luteinizálódott cystát tartalmaznak. Ellentétben a PCO-szindrómával, a tüszők nem apró, 5-9 mm közötti átmérőjűek, és nemcsak „gyöngysorszerúen” a kéregállományban helyezkednek el, hanem általában 10-40 mm közötti nagyságúak, és kitöltik a petefészek állományát. A hypoproteinaemia révén a vér ozmolaritása csökken, és a felszaporodó szabad hasűri folyadékkal együtt émelygés, hányinger, hirtelen testsúlygyarapodás figyelhető meg (3. ábra). Az ascites fokozódásával együtt megjelenő mellkasi folyadékgyülem a kórkép súlyosbodását jelenti. $\mathrm{Az}$ interstitiumba áramló folyadék az alsó végtagokban, ső́t akár testszerte kifejezett ödémát okozhat.

Az érpályán belüli folyadék mennyiségének csökkenésével és a képződő vazoaktív anyagok hatására a vérkerin- 


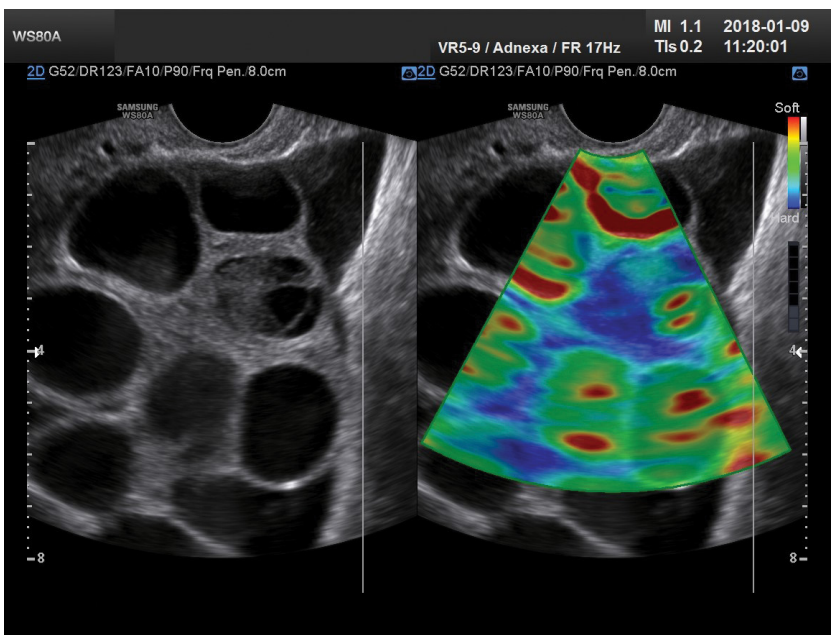

1. ábra

Elasztográfos ultrahangvizsgálattal a folyadékkal telt tüszők piros, sárga, zöld színekben, míg az ovuláció után luteinizálódott tüszők világoskék, sötétkék színekben ábrázolódnak

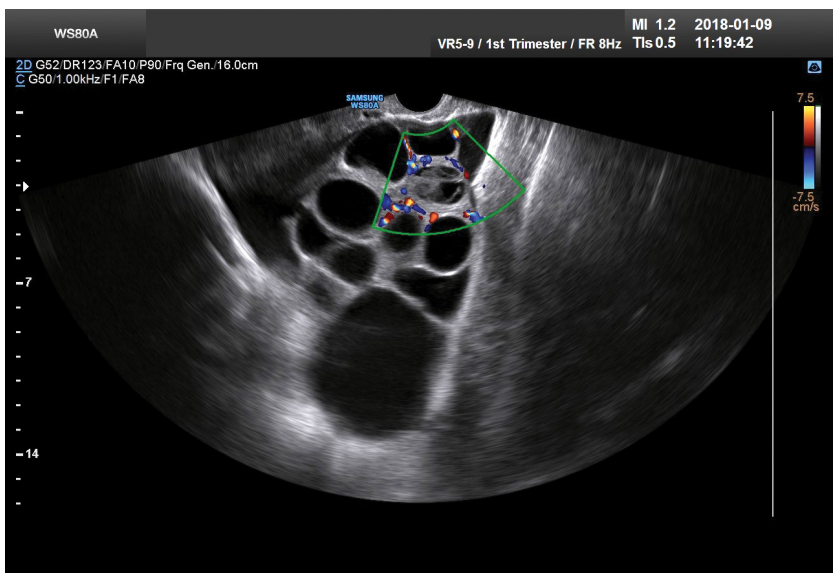

2. ábra

Hiperstimulált petefészekben color-Doppler-vizsgálattal a tüszők körül kifejezett érújdonképződés (neovascularisatio) figyelhető meg

gés lassul, a thrombosis kockázata megnő. A hypovolaemia mellett a sóháztartás is zavart szenved az esetek körülbelül 50\%-ában. Elsősorban hyponatraemia és hyperkalaemia alakul ki, mely szívritmuszavarhoz is vezethet. Az egyes szerveket a keringéselégtelenség változó mértékben érintheti. A máj és a vese múködési zavara általában megfigyelhető. A diagnosztizált esetek egyötödében megfigyelhető pleuralis folyadékgyülem mellett a szív diasztolés funkciós romlása következtében létrejövő tüdőödéma is légzési elégtelenséghez vezethet.

A fenti tünetek mellett egyéb szövődmények is kialakulhatnak. A petefészek méretének növekedésével bennük akár 6-8 centiméter átmérőjü cysták is kialakulhatnak, melyek megrepedése életveszélyes vérzést okozhat (4. ábra). A petefészek torquatiója is ritka, de életveszélyes kórkép [28]. A petefészket függesztő szalag (ligamentum suspensorium ovarii) megtekeredése következtében a benne futó erek elzáródhatnak. Jellemző tünetei közé a hirtelen szúró, éles hasi fájdalom, émelygés, há-

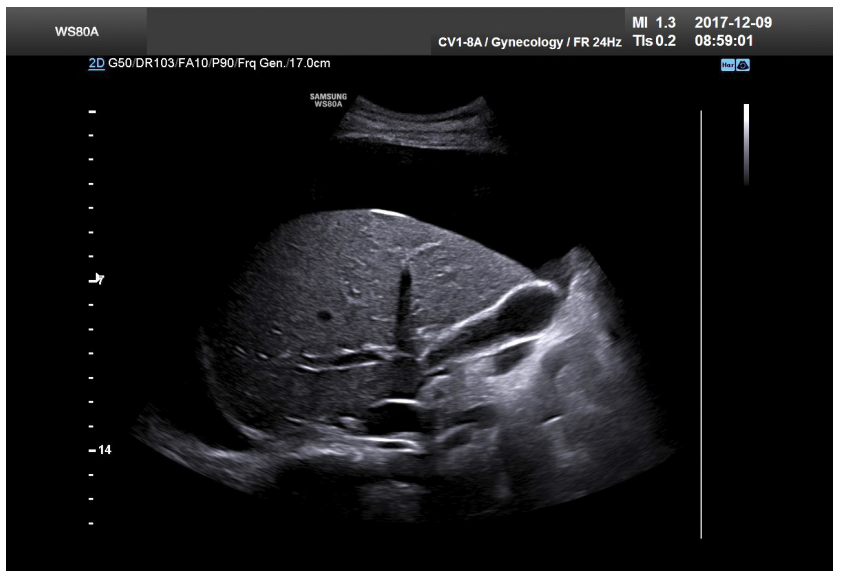

3. ábra

A felhasban, a jobb oldali rekeszív alatt a májat és az epehólyagot körbefolyó ascites (homogén echószegény terület) súlyos fokú OHSS miatt kezelt páciensnél

OHSS = ovarialis hiperstimulációs szindróma

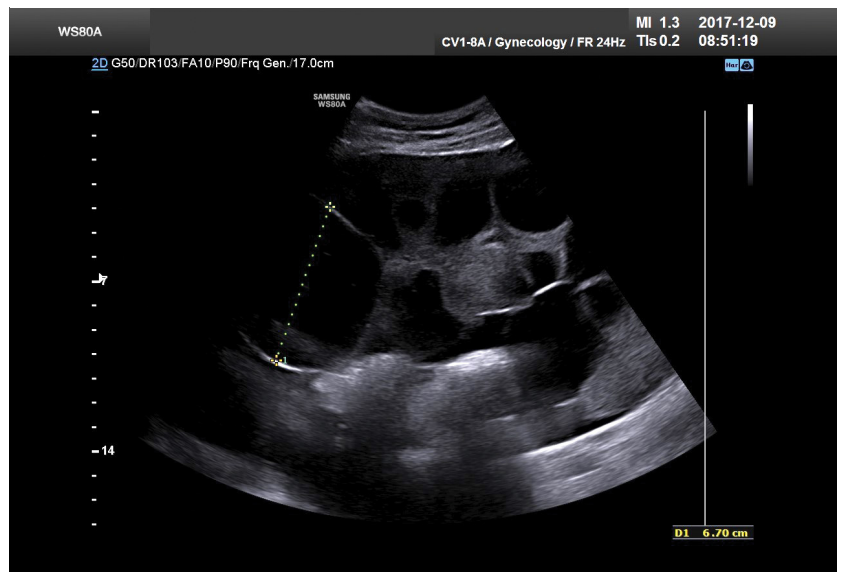

4. ábra

Közel 7 cm átmérōjú cysta egy hiperstimuláció által érintett petefészekben

nyás, vérnyomásesés, illetve a hirtelen fehérvérsejtszámemelkedés és a vérszegénység tartozik. Általában mütéti beavatkozást igényel.

A másik súlyos szövődmény a thromboemboliás károsodás létrejötte. Az OHSS miatt kezelt betegek 0,710\%-ában alakul ki [29]. Létrejöttében az ösztrogénszint emelkedése mellett mind a hemokoncentráció, mind a véralvadási rendszer aktiválódása szerepet játszik. Az esetek negyedében artériás, a többiben vénás thrombosis szerepel. Lokalizációját tekintve a mesenterialis, az axillaris, a kulcscsont alatti (subclavia) és a nyaki (jugularis interna) vénákban fordul elő a leggyakrabban [30]. A cerebrovascularis erek thrombosisa ischaemiás stroke képében jelentkezik. Ezért bármilyen szokatlan neurológiai tünet esetén, akár hetekkel az OHSS elmúlta után is gondolni kell a thromboemboliás szövődményre [31].

Veleszületett thrombophiliák esetén nem emelkedett az OHSS aránya IVF-kezelés esetén. Jelenleg nem is javasolt IVF-kezelések előtt általános szürésük. Ismert 
thrombophiliás páciensek IVF-kezelése előtt antikoaguláns profilaxis mérlegelendő.

Az OHSS hosszú távú következményeként a várandóst tájékoztatni kell jelen terhessége során a praeeclampsia és a koraszülés emelkedett kockázatáról [32, 33].

Differenciáldiagnózis: Az OHSS diagnózisa általában nem nehéz, tekintettel a jellegzetes kórelőzményre. Fiatal, fogamzóképes korban lévő nőknél azonban - különösen hormonkezelés vagy koraterhesség esetén - más kórképek is járhatnak hasi fájdalommal, illetve ultrahangvizsgálattal igazolható nagyméretü függeléktáji képlettel, vagy akár szabad hasüri folyadékkal. Ilyen lehet például a méhen kívüli terhesség vagy egy petefészekcysta bevérzése, megrepedése, illetve nem hiperstimulált petefészek torziója is. Az emelkedett fehérvérsejtszám, az elektrolitháztartás zavara, valamint a máj- és vesefunkciók romlása és a légzési elégtelenség szeptikus állapot mellett is kialakulhat. Ezért gondolni kell kismedencei fertőzésre, például a petefészkeket vagy a petevezetékeket és a Douglas-üreget is magában foglaló tályogra is. Nem nőgyógyászati okok közül a vékony- vagy akár a vastagbél perforációja is okozhat hasonló tüneteket, illetve laboreltéréseket.

\section{Osztályozás}

A betegség kialakulásának ideje szerint az OHSS-t két csoportra oszthatjuk. A korai kezdetû OHSS a hCG beadása utáni első 9 napban, általában a 3. és a 7. nap között jelentkezik. Exogén hCG-adás következménye, gyakran preklinikai vetéléssel jár. A késői kezdetű OHSS a hCG beadását követő 9 . nap után, általában a 12. és a 17. nap között alakul ki. Ennek a hátterében beágyazódott blastocysta általi endogén hCG-termelés áll. A késői kezdetü OHSS esetében a súlyos tünetek és szövődmények gyakoribbak [34].

A tünetek súlyossága alapján az OHSS-nek többféle beosztása is létezik. Rabau és munkatársai készítettek 1967-ben először a laboratóriumi eltérések és a panaszok alapján hatfokozatú súlyossági beosztást. 1978-ban Schenker és Weinstein három (enyhe, középsúlyos, súlyos) formára és szintén hat fokozatra módosították az osztályozást. A besorolások egyik hátránya volt, hogy 24 órás vizeletgyüjtést igényeltek az enyhe fokozatok elkülönítésében. Golan 1989-ben új, ötfokozatú beosztást javasolt. Ezek közül az első és a második fokozat az enyhe formához tartozik, ahol a petefészkek mérete 5 és 12 cm közötti. Az első fok hasi puffadással és diszkomfortérzéssel jár, a másodikban hányinger, hányás vagy hasmenés is jelentkezik. A középsúlyos forma a harmadik foknak felel meg, melyhez a $12 \mathrm{~cm}$ átmérö feletti petefészkek és az előző tünetek mellett testsúlygyarapodás és ultrahangvizsgálattal igazolt ascites társul. A súlyos formához a negyedik és az ötödik fokozat tartozik. A negyedikben a nehézlégzést okozó hasi és mellkasi folyadékgyülem alakul ki. A legsúlyosabb, ötödik fokozatot a fentieken túl kifejezett hemokoncentráció, a véralvadási rendszer fokozott múködése és csökkent veseperfúzió, oliguria jellemzi. Navot javaslatára 1992-ben az OHSS súlyos formájától elkülönült a kritikus forma. Ebbe a közvetlen életveszélyes állapotban lévő, több szervet érintően károsodott betegek tartoznak. Mathur 2005-ben háromfokozatú (enyhe, középsúlyos, súlyos) besorolást készített. Ebbe a besorolásba 2009-ben beleszerkesztette a kritikus formát mint negyedik fokozatot is. Jelenleg ezt alkalmazzák a legszélesebb körben. Az 1. táblázat is az American Society for Reproductive Medicine (ASRM), a Royal College of Obstetricians and Gynecologists (RCOG), illetve a The Society of Obstetricians and Gynaecologists of Canada (SGOC) által jelenleg használt beosztást tartalmazza [35-37]. Ennek alkalmazását javasoljuk a hazai gyakorlatban.

\section{Megelőzés}

A hajlamosító tényezők keresésén kívül egyéb lehetőségek is rendelkezésre állnak: a nem in vitro fertilizáció céljából végzett petefészek-stimulációs kezelések közül a lépcsőzetesen felépített (step-up) gonadotropinstimulációs protokollok alacsonyabb petefészek-túlmúködési rizikóval járnak a magas kezdő dózisról csökkenő (stepdown) protokollokhoz képest.

In vitro fertilizációs kezeléseknél a már említett GnRH-antagonista alkalmazása a korai spontán ovuláció megakadályozására szintén az OHSS megelőzésének egyik lehetséges módja [38].

Az ovulációt kiváltó hCG-dózis csökkentése, illetve e célból egyéb készítmények alkalmazása, például rekombináns $\mathrm{LH}$ - vagy GnRH-agonista adása szintén szóba jön $[39,40]$.

A lutealis fázis támogatására hCG helyett progeszteron (például $100 \mathrm{mg}$ hüvelykúp) alkalmazása ugyancsak csökkenti a szindróma kialakulásának kockázatát, ezért napjainkban szinte kizárólag ezt a készítményt adjuk a sárgatestmúködés támogatására [41].

Megelőzésnek tekinthető az ikerterhességek esetében gyakoribb OHSS elkerülése érdekében, hogy az embriótranszferek során csak egy preembrió kerül visszaültetésre.

A hyperinsulinaemiában szenvedő PCO-s betegek esetében az inzulinszint csökkentése céljából adott metformin alkalmazása jótékonynak bizonyult. PCO-s betegek IVF-kezelése során alkalmazott metformin mellett az OHSS kialakulása szignifikánsan ritkább volt a kontrollcsoporthoz képest $[42,43]$.

A dopaminagonista kabergolin a VEGF2-receptor inaktiválásával gátolja a VEGF indukálta érpermeabilitásfokozódást. A petesejtnyerés után megkezdett $0,5 \mathrm{mg}$ / nap dózis mellett az ascites és a hemokoncentráció, illetve a középsúlyos OHSS kialakulási gyakoriságának 50\%os csökkenését észlelték [44]. Az eredmények azonban ellentmondásosak, és kései OHSS így is előfordulhat. 
1. táblázat $\quad$ Az ovarialis hiperstimulációs szindróma súlyossági forma szerinti beosztása

(A Royal College of Obstetricians and Gynaecologists 2016. februári útmutatója alapján)

\begin{tabular}{|c|c|}
\hline $\begin{array}{l}\text { OHSS-súlyossági } \\
\text { forma }\end{array}$ & Tünetek, laboreltérések \\
\hline Enyhe & $\begin{array}{l}\text { - Hasfeszülés } \\
\text { - Émelygés, hányinger, hasmenés } \\
\text { - Megnövekedett, de általában } 8 \mathrm{~cm} \text { alatti } \\
\text { petefészkek } \\
\text { - Jellegzetes laboreltérés nem igazolható }\end{array}$ \\
\hline Középsúlyos & $\begin{array}{l}\text { - Megnövekedett haskörfogat, naponta többszöri, } \\
\text { profúz hányás } \\
\text { - Tapintható cysták, megnövekedett, általában } \\
8-12 \mathrm{~cm} \text { közötti, de akár } 12 \mathrm{~cm} \text { feletti átmérőjű } \\
\text { petefészkek } \\
\text { - Ultrahangvizsgálattal igazolt szabad hasűri } \\
\text { folyadék, ascites } \\
\text { - Testsúlygyarapodás: } 3-4 \text { napon belül: >3 kg } \\
\text { - Hemokoncentráció: >41\%, fehérvérsejtszám: } \\
\text { >15 G/1, hypoproteinaemia: } 35-60 \mathrm{~g} / 1\end{array}$ \\
\hline Súlyos & $\begin{array}{l}\text { - Klinikai panaszokat okozó hasi és mellkasi } \\
\text { folyadékgyülem } \\
\text { - Nehézlégzés, hypoxia } \\
\text { - Megnövekedett, általában } 12 \mathrm{~cm} \text { feletti } \\
\text { petefészkek } \\
\text { - Hemokoncentráció: >45\%, fehérvérsejtszám: } \\
\text { >15 G/1, kreatinin: } 1,0-1,5 \mathrm{mg} / \mathrm{dl} \text {, kreatinin- } \\
\text { clearance: } \geq 50 / \mathrm{ml} / \mathrm{min} \\
\text { - Hyponatraemia: }<135 \mathrm{mmol} / 1 \text {, hyperkalaemia: } \\
>5 \text { mmol/1, hipoozmolaritás: <282 mOsm/kg, } \\
\text { hypoproteinaemia: <35 g/1 } \\
\text { - Anasarca, a májfunkció zavara, emelkedett } \\
\text { transzaminázok } \\
\text { - Testsúlygyarapodás: } 5-10 \text { napon belül: }>15-20 \\
\text { kg }\end{array}$ \\
\hline Kritikus & 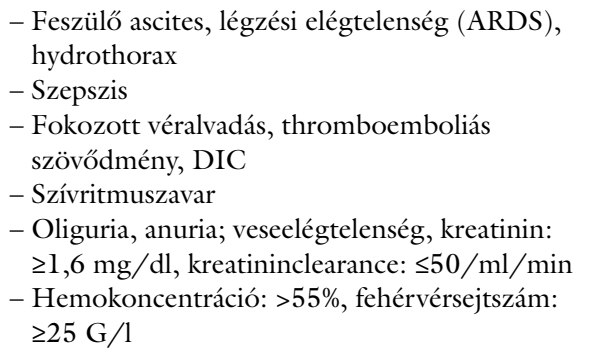 \\
\hline
\end{tabular}

ARDS = akut légúti distressz szindróma, légzési elégtelenség; DIC = disszeminált intravascularis koaguláció; OHSS = ovarialis hiperstimulációs szindróma

A kabergolin jelenleg nem törzskönyvezett hatóanyag hazánkban.

A stimuláció első napjától aszpirin alacsony dózisú (100 mg/nap) alkalmazásának jótékony hatását hazai szerzők publikálták. Ennek hátterében az asszisztált reprodukciós kezelés következményeként kialakuló vérlemezke-aktiváció gátlása állhat [45].

Amennyiben az alkalmazott stimuláció során a petefészek fokozott válaszának gyanúja merül fel, a másodlagos megelőzés különböző lehetőségei még fennállnak. Az egyik lehetőség magas ösztrogénszint esetén, hogy a petesejtleszívás tervezett napja előtt néhány nappal a stimu- láció felfüggesztésre kerül. Ez az úgynevezett „coasting” eljárás [46]. A gonadotropin-, illetve a hCG-kezelés átmeneti szüneteltetésével az ösztradiolszint csökkenésnek indul, és a petesejtleszívás idejére már biztonságos értékre esik vissza.

Egy másik nagyon sokat ígérő lehetőség a hagyományosan végzett petesejtleszívás után a fejlődésnek induló összes embrió (vagy petesejtek) lefagyasztása, azaz a beültetés átmeneti késleltetése. Ez az úgynevezett „freeze all” technika [47]. Ennek elméleti hátterét az adja, hogy a lutealis fázis támogatása, illetve az embrióbeültetés után az embrió vagy embriók sikeres megtapadása, azaz a kialakuló terhesség súlyosbíthatja az OHSS-t. A beültetés késleltetésével a petefészkek nyugalmi állapotba kerülnek, ezt követően a felolvasztott embriók beültetésre kerülhetnek. A fagyasztott ciklusban már nincs szükség a petefészkek újbóli stimulálására. Újabb eredmények alapján ez a módszer minimálisra csökkenti a korai OHSS kialakulásának veszélyét in vitro fertilizációs kezelések esetén. A kései kezdetú OHSS elméleti valószínúsége azonban ebben az esetben fennállhat $[48,49]$.

A harmadik lehetőség a kezelési ciklus leállítása. Ez azonban mind a páciensek érzelmi ellenállását, mind anyagi következményeket von maga után.

\section{Kezelés}

A kialakult OHSS kezelése a súlyossági beosztás alapján általában konzervatív és tüneti. A legtöbb érintett, fóként az enyhe és középsúlyos páciensek járó betegként elláthatók. Az ennél súlyosabb állapotúak azonban kórházi felvételt, akár intenzív osztályos kezelést is igényelhetnek. Az OHSS önmagát korlátozó, általában egy-két hét alatt lezajló betegség. Terhesség létrejötte esetén az endogén hCG emelkedése miatt számítani kell a tünetek akár nyolc-tíz hétig tartó elhúzódására.

Az OHSS enyhe formájában a napi 2-3 liter folyadék ellenőrzőtt bevitele mellett a hasfeszülés fájdalmának csökkentésére fájdalomcsillapítók, elsősorban paracetamol/acetaminofen szájon át történő adása javasolt. Nemszteroid gyulladásgátlók adása a vesefunkció romlásának veszélye miatt nem javasolt. A fizikai megterhelés szintén kerülendő. Szigorú ágynyugalom azonban nem indokolt, mert ez csak a thromboemboliás szövődmények kockázatát növelné. A betegeket tájékoztatni kell a lehetséges szövődmények tüneteiről (nehézlégzés, több napon keresztül a napi l kilogrammot meghaladó testsúlygyarapodás, erős hasi fájdalom, a haskörfogat növekedésével járó puffadás, a vizelet mennyiségének csökkenése). Ezek megjelenése esetén a pácienseknek soron kívül jelentkezniük kell a kezelőintézetben [35].

Középsúlyos OHSS esetén is lehetséges a páciens járó betegként történő ellátása. Ehhez a napi kapcsolattartás (telefon, e-mail vagy személyes találkozás) lehetőségének biztosítására van szükség. A két-három naponta esedékes személyes találkozások kapcsán fizikális vizsgálat, hüvelyi-kismedencei ultrahangvizsgálat végzése indo- 
kolt. Laboratóriumi vizsgálat során a vérkép, az elektrolit, az összfehérje, a szérumalbumin, a vesefunkció (karbamid, GFR) és a májfunkció ellenőrzése javasolt. A sorozat-szérum-béta-hCG-vizsgálat korán igazolhatja a megfogant terhességet és annak fejlődését.

A folyadékháztartás vizsgálata során ellenőrizni kell, hogy a páciens legalább két liter folyadékot megiszik-e naponta. Az ennél szigorúbb kötelező folyadékbevitelmeghatározás nem hatékony. Az egyénre szabott folyadékbevitelt a szomjúságérzethez érdemes kötni. Azonban vezetni, vezettetni kell a folyadékfelvétel és -leadás mennyiségét. A testsúly és a haskörfogat mérését szintén írásban javasolt rögzíteni minden alkalommal. A csökkenő testsúly, a folyadékfelvétel és -leadás negatív irányba történő változása a gyógyulás kezdeti jelei lehetnek. Fordított helyzetben, azaz a folyadékegyensúly $1000 \mathrm{ml} /$ nap feletti pozitív értéke, illetve a vizeletürítés $1000 \mathrm{ml} /$ nap alá csökkenő szintje esetén a tünetek súlyosbodására lehet számítani [36].

Vízhajtók adása az intravénás folyadékmennyiség további csökkenése miatt általában kerülendő. Alkalmazásuk csak megfelelő mennyiségű folyadékbevitel ellenére sem jelentkező diuresis megindítása céljából, kórházi körülmények között jön szóba. Gyakori hányás, hasmenés, illetve a szájon át történő megfelelő mennyiségű folyadékbevitel képtelensége kivételével az intravénás folyadékpótlás rutinszerü alkalmazása az ascites hirtelen fokozódásának kockázata miatt enyhe-középsúlyos OHSS esetében nem indokolt. Az ascites fokozott hasúri nyomásfokozódáshoz, így mintegy kompartment szindrómaként a hasüri zsigerek és az őket ellátó erek összenyomódásához vezethet.

Ultrahangvizsgálattal nemcsak a kismedencében, hanem a felhasban is észlelt, panaszokat okozó ascites esetén a hasüri folyadék punkciója és leengedése révén a hasűri nyomásfokozódás csökkenthető, a további szövődmények megelőzhetők, a kórházi felvétel elkerülhető [50] (3. ábra). A beteg a tehermentesítés után panaszmentessé válhat. Minden esetben ultrahangvezérlés mellett javasolt a paracentesis. A paracentesis hasfalon keresztül végezve is hatásos. Egyes munkacsoportok a bélsérülések elkerülése érdekében a hüvelyi ultrahangvezérlés mellett végzett Douglas-punkciót (culdocentesis) is ajánlják. Saját gyakorlatunkban azonban a felhasban végezve a hasfalon végzett paracentesis mellett egyetlen alkalommal sem következett be ilyen szövődmény. Egy punkció kapcsán általában 500-2000 ml közötti folyadék lebocsátása hatásosnak bizonyul. Amennyiben ez nem elég, akár 4-6 liter ascites ürítése is lehetséges. Az így elvesztett folyadék, fehérje és elektrolit szájon át történő, szükség esetén intravénás pótlása indokolt. Sikeres punkció és panaszmentessé válás esetén az ambuláns ellátás folytatható. Antibiotikumprofilaxis mérlegelendő.

A thrombosisprofilaxis megkezdésének az OHSS tüneteinek észlelése esetén friss vérzés kivételével nincs ellenjavallata. Thrombosisprofilaxis megkezdése indokolt, amennyiben az ambulánsan kezelt betegnél legalább két rizikótényező fennáll az alábbiak közül: megfogant terhesség, 35 év feletti életkor, elhízás (35 feletti BMI), elrendelt tartós ágynyugalom, a beteg kórelőzményében és/vagy a családi anamnézisben szereplő thrombosis, thrombophilia. Alacsony molekulatömegü heparin adása mellett kompressziós harisnya vagy gépi pneumatikus kompresszió alkalmazása is indokolt lehet. A szubjektív panaszok fokozódása vagy a laborértékek hirtelen romlása esetén kórházi felvétel javasolt az OHSS-ellátásban tapasztalt és az asszisztált reprodukciós intézménnyel kapcsolatot tartó szülészeti központba.

Az OHSS súlyos formájával jelentkező nők számára a fekvőbeteg-ellátás kötelező. A tünetek közül a csillapíthatatlan hányás és hasi fájdalom, oliguria, anuria, feszülő ascites, ájulással, esetleg tudatzavarral járó vérnyomásesés, illetve nehézlégzés vagy szapora légzés mind kórházi felvételi indikáció lehet. A panaszok mellett a laborértékek közül önmagában a 45\% feletti hematokrit, a 25 G/l feletti fehérvérsejtszám, a máj transzamináz enzimeinek hirtelen emelkedése vagy a több, mint 1,6 mg/dl feletti kreatininszint is indokolttá teszi a fekvőbeteg-ellátást. Kivételesen a compliance hiánya vagy a rendszeres kontrollvizsgálatra járás képtelensége szintén oka lehet a hospitalizációnak. Egy finn vizsgálat alapján az ovulációindukciós kezelésben részesült páciensek 0,4 ezreléke, míg az IVF útján kezeltek 9,3 ezreléke került OHSS miatt kórházi felvételre [51].

A kórházi kezelés fó elemei a létfenntartó szervrendszerek támogatása (szupportív terápia), a beteg élettani paramétereinek folyamatos megfigyelése (monitorizálás) és a súlyos szövődmények megelőzése, bekövetkezésük esetén azok gyógyítása.

A szupportív kezelés fó célja az érpályában lévő vértérfogat biztosítása. A folyadékpótlás elsősorban izotóniás krisztalloidokkal történik. Amennyiben 1000 ml fiziológiás sóoldat infúziója esetén a vizeletürítés megfelelő, és a hemokoncentráció mérséklődik, glükózoldat (500$1000 \mathrm{ml} \mathrm{5 \% -os} \mathrm{dextrózoldat,} \mathrm{infúziós} \mathrm{pumpával} \mathrm{125-}$ $150 \mathrm{ml} / \mathrm{h}$ sebességgel) kezdhető. Nem megfelelő vizeletürítés esetén kolloid oldatok (hiperozmotikus hidroxi-etil-keményítő-tartalmú plazmapótszerek) adhatók. Megfelelő vesefunkció mellett alacsony szérum-összfehérje- és -albuminszint esetén humán albumininfúzió ( $20 \mathrm{~g} 100 \mathrm{ml}$ infúzióban 8-12 óránként ismételve) adása mérlegelendő. Invazív hemodinamikai monitorizálásra, centrális vénás nyomás mérésére szükség lehet a folyadékpótlás megfelelő mennyiségének igazolására. A vizelet megindítására adott diuretikumok (furoszemid iv.) vagy a vesemúködést támogató, a veseereket tágító alacsony dózisú dopamin $(0,18 \mathrm{mg} / \mathrm{kg} / \mathrm{h})$ intravénás adagolása csak intenzív osztályos megfigyelés mellett javasolt. Párhuzamosan az elektrolit-háztartás egyensúlyban tartása (például profúz hányás esetén intravénás káliumpótlás) is fontos.

A testüregekbe kiáramlott és panaszokat okozó folyadékgyülemek közül az ascites kezeléséről már szóltunk. A súlyos fokú OHSS tüneteként megjelenő pleuralis fo- 
lyadékgyülemet is szükség esetén le kell bocsátani. A beavatkozás ultrahangvezérlés mellett történik, és a sikeres kezelés után is mellkasröntgen, illetve ultrahangvizsgálat végzése javasolt. Átmeneti lélegeztetés ARDS esetén szükséges lehet. A klinikai panaszokat okozó pericardialis folyadékgyülem ritka, az elmúlt húsz évben ilyen szövődmény Klinikánkon nem fordult elő.

$\mathrm{Az}$ antibiotikumkezelés nem obligát része az ovarium hiperstimulációs szindróma kezelésének. Az emelkedett fehérvérsejtszám részben a hemokoncentráció következménye. A keringés zavara révén létrejövő csökkent szöveti perfúzió, a magas hormonszintek következményeként kialakuló deprimált immunstatus és a hospitalizáció melletti nosocomialis kórokozók azonban hajlamosítanak a fertőzésekre. Kialakult fertőzés, egyéb tünetek (láz, magas CRP) esetén az antibiotikumkezelés célszerü.

A sebészi kezelés nem tartozik az OHSS rutinellátási formái közé. Az elmúlt évtizedekben megszűnt az a korábbi gyakorlat, hogy a súlyos vagy kritikus fokú OHSS esetén a megfoganó terhesség megszakításával kelljen megszüntetni az anyát veszélyeztető betegséget. Az elmúlt tíz évben nem történt ilyen beavatkozás Klinikánkon. Korábban egy-egy külföldi publikációban még azt is közölték, hogy a túlstimulálódott petefészkek eltávolítására is sor kerülhetett a gyógyulás érdekében [52]. Ez egyrészt nem bizonyult hatásos kezelési módnak, másrészt a hosszú távú következmények etikailag is megkérdőjelezik létjogosultságát, így ma nem tartozik az ajánlott kezelési módszerek közé [53]. A szövődmények elhárítása során azonban szükség lehet nyitott vagy a legtöbbször laparoszkópos mútétre. Ilyen lehet a méhen kívüli terhesség eltávolítása vagy a petefészkek torquatiójának megszüntetése. Ultrahangvizsgálattal keringést mutató, mütét közben detorkvált és múködőképesnek mutatkozó petefészkek konzerválása lehetséges. A megnagyobbodott, fokozott erezettséget mutató petefészkek azonban sérülékenyek, és az utóvérzés mütéti kockázata magas.

Anyagi támogatás: A közlemény megírása anyagi támogatásban nem részesült.

Szerzői munkamegosztás: Sz. G., M. Á., U. J.: A kézirat elkészítése. P. D., Á. A.: Irodalomkutatás. R. J. Jr.: A közlemény szerkesztésének megtervezése. A cikk végleges változatát valamennyi szerző elolvasta és jóváhagyta.

Érdekeltségek: A szerzőknek a közleményhez kapcsolódó közvetlen érdekeltségeik nincsenek.

\section{Irodalom}

[1] Rydberg E, Pedersen-Bjergaard K. Effect of serum gonadotropin and chorionic gonadotropin on the human ovary. JAMA 1943; 121: 1117-1122.

[2] Budev MM, Arroliga AC, Falcone T. Ovarian hyperstimulation syndrome. Crit Care Med. 2005; 33: S301-S306.
[3] Urbancsek J, Rabe T, Strowitzki T. Ovarian stimulation for in vitro fertilization: Past and present. In: Rabe T, Dietrich $\mathrm{K}$, Strowitzki T. (eds.) Manual on assisted reproduction. Springer Verlag, Berlin, 2000; pp. 165-195.

[4] Urbancsek J, Fancsovits P. In vitro fertilisation. In: Papp Z. (ed.) The handbook of gynaecology. [Szervezeten kívüli megtermékenyítés. In: Papp Z. (szerk.) A nőgyógyászat kézikönyve.] Medicina Könyvkiadó, Budapest, 2016; pp. 335-358. [Hungarian]

[5] Binder H, Dittrich R, Einhaus F, et al. Update on ovarian hyperstimulation syndrome: Part 1 . Incidence and pathogenesis. Int $\mathrm{J}$ Fertil Womens Med. 2007; 52: 11-26.

[6] Cunha-Filho JS, Samama M, Fanchin R, et al. Clinical and laboratory evaluation of hospitalized patients with severe ovarian hyperstimulation syndrome. Reprod Biomed Online 2003; 6: 448-451.

[7] Herczeg Z, Vanya M, Szili K, et al. Genetic and epigenetic factors of polycystic ovary syndrome. [Genetikai és epigenetikai faktorok polycystás ovarium szindróma esetén.] Orv Hetil. 2016; 157: 1275-1281. [Hungarian]

[8] Tummon I, Gavrilova-Jordan L, Allemand MC, et al. Polycystic ovaries and ovarian hyperstimulation syndrome: a systematic review. Acta Obstet Gynecol Scand. 2005; 84: 611-616.

[9] Hehenkamp WJ, Looman CW, Themmen AP, et al. Anti-Mullerian hormone levels in the spontaneous menstrual cycle do not show substantial fluctuation. J Clin Endocrinol Metab. 2006; 91: 4057-4063.

[10] Iliodromiti S, Anderson RA, Nelson SM. Technical and performance characteristics of anti-Mullerian hormone and antral-follicle count as biomarkers of ovarian response. Hum Reprod Update 2015; 21: 698-710.

[11] Martins WP, Kollmann M, Raine-Fenning N. Counting ovarian follicles: updated threshold for diagnosis of hyperandrogenic anovulation. Ultrasound Obstet Gynecol. 2014; 44: 131-134.

[12] Luke B, Brown MB, Morbeck DE, et al. Factors associated with ovarian hyperstimulation syndrome (OHSS) and its effect on assisted reproductive technology (ART) treatment and outcome. Fertil Steril. 2010; 94: 1399-1404.

[13] Cupisti S, Emran J, Mueller A, et al. Course of ovarian hyperstimulation syndrome in 19 intact twin pregnancies after assisted reproduction techniques, with a case report of severe thromboembolism. Twin Res Hum Genet. 2006; 9: 691-696.

[14] Navot D, Bergh PA, Laufer N. Ovarian hyperstimulation syndrome in novel reproductive technologies: prevention and treatment. Fertil Steril. 1992; 58: 249-261.

[15] Wang TH, Horng SG, Chang CL, et al. Human chorionic gonadotropin-induced ovarian hyperstimulation syndrome is associated with up-regulation of vascular endothelial growth factor. J. Clin Endocrinol Metab. 2002; 87: 3300-3308.

[16] Levin ER, Rosen GF, Cassidenti DL, et al. Role of vascular endothelial cell growth factor in ovarian hyperstimulation syndrome. J Clin Invest. 1998; 102: 1978-1985.

[17] Gómez R, Soares SR, Busso C, et al. Physiology and pathology of ovarian hyperstimulation syndrome. Semin Reprod Med. 2010; 28 : 448-457.

[18] Soares SR, Gómez R, Simón C, et al. Targeting the vascular endothelial growth factor system to prevent ovarian hyperstimulation syndrome. Hum Reprod Update 2008; 14: 321-333.

[19] Villasante A, Pacheco A, Ruiz A, et al. Vascular endothelial cadherin regulates vascular permeability: implications for ovarian hyperstimulation syndrome. J Clin Endocrinol Metab. 2007; 92: 314-321.

[20] Vasseur C, Rodien P, Beau I, et al. A chorionic gonadotropinsensitive mutation in the follicle-stimulating hormone receptor as a cause of familial gestational spontaneous ovarian hyperstimulation syndrome. N Engl J Med. 2003; 349: 753-759.

[21] Montanelli L, Delbaere A, Di Carlo C, et al. A mutation in the follicle-stimulating hormone receptor as a cause of familial spon- 
taneous ovarian hyperstimulation syndrome. J Clin Endocrinol Metab. 2004; 89: 1255-1258.

[22] Smits G, Olatunbosun O, Delbaere A, et al. Ovarian hyperstimulation syndrome due to a mutation in the follicle-stimulating hormone receptor. N Engl J Med. 2003; 349: 760-766.

[23] Chauhan AR, Prasad M, Chamariya S, et al. Novel FSH receptor mutation in a case of spontaneous ovarian hyperstimulation syndrome with successful pregnancy outcome. J Hum Reprod Sci. 2015; 8: 230-233.

[24] Morón FJ, de Castro F, Royo JL, et al. Bone morphogenetic protein 15 (BMP15) alleles predict over-response to recombinant follicle stimulation hormone and iatrogenic ovarian hyperstimulation syndrome (OHSS). Pharmacogenet Genomics 2006; 16: 485-495.

[25] Borna S, Nasery A. Spontaneous ovarian hyperstimulation in a pregnant woman with hypothyroidism. Fertil Steril. 2007; 88: $705 \mathrm{e} 1-705 \mathrm{e} 3$

[26] Miras AD, Mogford JT, Wright J. Ovarian hyperstimulation from ectopic hypersecretion of follicle stimulating hormone. Lancet 2015; 385: 392

[27] Várnagy Á, Wilhelm F, Mánfai Z, et al. Ovarian hyperstimulation syndrome. [Ovariális hyperstimulációs szindróma.] Magy Nőorv L. 2010; 73: 175-180. [Hungarian]

[28] Mashiach S, Bider D, Moran O, et al. Adnexal torsion of hyperstimulated ovaries in pregnancies after gonadotropin therapy. Fertil Steril. 1990; 53: 76-80.

[29] Serour GI, Aboulghar M, Mansour R, et al. Complications of medically assisted conception in 3500 cycles. Fertil Steril. 1998; 70: 638-642.

[30] El-Ghazali A, Hill D. Internal jugular vein thrombosis due to ovarian hyper-stimulation syndrome. J Laryngol Otol. 2005; 119: 737-739.

[31] Bereczki D Jr. Pregnancy and acute ischemic stroke. [Terhesség és akut ischaemiás stroke.] Orv Hetil. 2016; 157: 763-766. [Hungarian]

[32] Abramov Y, Elchalal U, Schenker JG. Obstetric outcome of in vitro fertilized pregnancies complicated by severe ovarian hyperstimulation syndrome: a multicenter study. Fertil Steril. 1998; 70: 1070-1076

[33] Mathur RS, Jenkins JM. Is ovarian hyperstimulation syndrome associated with a poor obstetric outcome? BJOG 2000; 107: 943-946.

[34] Mathur RS, Akande VA, Keay SD, et al. Distinction between early and late ovarian hyperstimulation syndrome. Fertil Steril. 2000; 73: 901-907.

[35] Royal College of Obstetricians and Gynecologists. The management of ovarian hyperstimulation syndrome. Green-top guideline No. 5. February 2016. Available from: https://www.rcog. org.uk/globalassets/documents/guidelines/green-top-guidelines/gtg_5_ohss. pdf

[36] Practice Committee of the American Society for Reproductive Medicine. Prevention and treatment of moderate and severe ovarian hyperstimulation syndrome: a guideline. Fertil Steril. 2016; 106: 1634-1647

[37] Corbett S, Shmorgun D, Claman P. The prevention of ovarian hyperstimulation syndrome. J Obstet Gynaecol Can. 2014; 36: 1024-1033.

[38] Engmann L, DiLuigi A, Schmidt D. The use of gonadotropinreleasing hormone $(\mathrm{GnRH})$ agonist to induce oocyte maturation after cotreatment with GnRH antagonist in high-risk patients undergoing in vitro fertilization prevents the risk of ovarian hyperstimulation syndrome: a prospective randomized controlled study. Fertil Steril. 2008; 89: 84-91.
[39] Iliodromiti S, Blockeel C, Tremellen KP, et al. Consistent high clinical pregnancy rates and low ovarian hyperstimulation syndrome rates in high-risk patients after $\mathrm{GnRH}$ agonist triggering and modified luteal support: a retrospective multicentre study. Hum Reprod. 2013; 28: 2529-2536.

[40] Youssef MA, Van der Veen F, Al-Inany HG, et al. Gonadotropinreleasing hormone agonist versus HCG for oocyte triggering in antagonist-assisted reproductive technology. Cochrane Database Syst Rev. 2014; (10): CD008046.

[41] Humaidan P, Papanikolaou EG, Kyrou D, et al. The luteal phase after GnRH-agonist triggering of ovulation: present and future perspectives. Reprod Biomed Online 2012; 24: 134-141.

[42] Tang T, Glanville J, Orsi N, et al. The use of metformin for women with PCOS undergoing IVF treatment. Hum Reprod. 2006; 21: 1416-1425.

[43] Palomba S, Falbo A, Carillo L, et al. Metformin reduces risk of ovarian hyperstimulation syndrome in patients with polycystic ovary syndrome during gonadotropin-stimulated in vitro fertilization cycles: a randomized, controlled trial. Fertil Steril. 2011; 96: 1384-1390.e4.

[44] Alvarez C, Marti-Bonmati L, Novella-Maestre E, et al. Dopamine agonist cabergoline reduces hemoconcentration and ascites in hyperstimulated women undergoing assisted reproduction. J Clin Endocrinol Metab. 2007; 92: 2931-2937.

[45] Várnagy A, Bódis J, Mánfai Z, et al. Low-dose aspirin therapy to prevent ovarian hyperstimulation syndrome. Fertil Steril. 2010; $93 ; 2281-2284$.

[46] Grochowski D, Wołczyński S, Kuczyński W, et al. Correctly timed coasting reduces the risk of ovarian hyperstimulation syndrome and gives good cycle outcome in an in vitro fertilization program. Gynecol Endocrinol. 2001; 15: 234-238.

[47] Ferraretti AP, Gianaroli L, Magli C, et al. Elective cryopreservation of all pronucleate embryos in women at risk of ovarian hyperstimulation syndrome: efficiency and safety. Hum Reprod. 1999; 14: 1457-1460.

[48] Griesinger G, von Otte S, Schroer A, et al. Elective cryopreservation of all pronuclear oocytes after GnRH agonist triggering of final oocyte maturation in patients at risk of developing OHSS: a prospective, observational proof-of-concept study. Hum Reprod. 2007; 22: 1348-1352.

[49] Devroey P, Polyzos NP, Blockeel C. An OHSS-free clinic by segmentation of IVF treatment. Hum Reprod. 2011; 26: 25932597.

[50] Levin I, Almog B, Avni A, et al. Effect of paracentesis of ascitic fluids on urinary output and blood indices in patients with severe ovarian hyperstimulation syndrome. Fertil Steril. 2002; 77: 986988.

[51] Klemetti R, Sevón T, Gissler M, et al. Complications of IVF and ovulation induction. Hum Reprod. 2005; 20: 3293-3300.

[52] Amarin ZO. Bilateral partial oophorectomy in the management of severe ovarian hyperstimulation syndrome. An agressive, but perhaps life-saving procedure. Hum Reprod. 2003; 18: 659664.

[53] Bellver J, Escudero E, Pellicer A. Bilateral partial oophorectomy in the management of severe ovarian hyperstimulation syndrome (OHSS): ovarian mutilating surgery is not an option in the management of severe OHSS. Hum Reprod. 2003; 18: 1363-1367.

(Szabó Gábor dr., Budapest, Baross u. 27., 1088 e-mail: szabo.gabor@noil.sote.hu)

A cikk a Creative Commons Attribution-NonCommercial 4.0 International License (https://creativecommons.org/licenses/by-nc/4.0) feltételei szerint publikált Open Access közlemény, melynek szellemében a cikk nem kereskedelmi célból bármilyen médiumban szabadon felhasználható, megosztható és újraközölhető, feltéve, hogy az eredeti szerző és a közlés helye, illetve a CC License linkje és az esetlegesen végrehajtott módositások feltüntetésre kerülnek. 